\title{
PERKEMBANGAN ANAK USIA DINI (AUD) DI TK AISYIYAH: PROBLEMATIKA DAN SOLUSI
}

\author{
Nur Kholidah Nasution \\ Universitas Islam Negeri Mataram \\ Email: nurkhalidah920@gmail.com
}

\begin{abstract}
Abstrak: Penelitian ini membahas problematika dan solusi perkembangan Anak Usia Dini (AUD) TK Aisyiyah Bustanul Atfal Sapen Yogyakarta. Penelitian ini merupakan penelitian kualitatif dengan pendekatan studi kasus. Teknik pengumpulan data menggunakan observasi, wawancara dan dokumentasi. Sedangkan analisis data menggunakan model analisis Mills \& Hubberman yang meliputi; reduksi data, penyajian data, dan verification. Hasil penelitian bahwa pendidikan anak usia dini merupakan masa emas yang hanya datang sekali dan tidak dapat diulang. Guru dan orang tua wajib untuk melihat perkembangan anak, karena upaya untuk menstimulus anak sejak dini sangat penting. Dan betapa ruginya keluarga, atau orang tua yang tidak peduli dengan perkembangan anak. Oleh karena itu sebagai orang tua harus memahami pertumbuhan dan perkembangan anak, dan mengerti akan kebutuhan anak sesuai dengan umurnya, tanpa harus memaksa anak dengan kekerasan. Tetapi mendidik anak dengan menyenangkan serta penuh dengan cinta dan kasih sayang.
\end{abstract}

Kata kunci: Problematika, solusi, perekembangan anak usia dini, taman kanak-kanak, TK Aisyiyah

Title: Early Childhood Development (AUD) at TK Aisyiyah Kindergarten: Problems and Solutions

Abstract: This research intends to examine the problematics and its solutions in early childhood developmental (AUD) at TK Aisyizab Bustanul Atfal Sapen Yogyakarta. This study uses a qualitative approach with type of case study. The collecting data uses observation, interview and documentation. While data analysis uses data reduction, data presentation and verification. The results of research that early childhood education is primal period and only comes one time and can't be repeated. Teachers and parents are obliged to behold physical development of the child, both teachers and parents efforts to stimulate for cbildren. Therefore, as parents must be understand growing and developmental cognitive and psychomotor of their children, and also should understand what children need according to their age, without having forces or violence.

Keywords: Problematics, solutions, early childhood development, kindergarten, TK Aisyiyah. 


\section{PENDAHULUAN}

Anak usia dini merupakan individu yang berbeda, unik, dan memiliki karakteristik tersendiri sesuai dengan tahapan usianya. Masa usia dini merupakan masa keemasan (Golden age) di mana stimulus seluruh aspek perkembangan anak berperan penting untuk tugas perkembangan selanjutnya. Usia dini merupakan masa awal kehidupan anak dan merupakan masa terpenting dalam rentan kehidupan seorang individu. Pada masa ini, seluruh aspek perkembangan meliputi: motorik, bahasa, kognitif, sosial, emosional dan moral mengalami perkembangan yang sangat pesat sehingga memerlukan bimbingan agar seluruh potensinya berkembang secara optimal. ${ }^{1}$ Anak sebagai generasi unggul pada dasarnya tidak akan tumbuh dan berkembang sendiriny. Mereka sungguh memerlukan lingkungan subur yang khusus diciptakan untuk itu.

Lingkungan yang kondusif tersebut akan memungkinkan anak untuk berkembang secara optimal. Dalam hal ini, peran orang tua amatlah penting. Menurut UU PA, anak mempunyai hak untuk tumbuh dan berkembang, bermain, beristirhat, berekreasi, dan belajar dalam suatu pendidikan. Jadi belajar adalah hak anak, bukan kewajiban. Orang tua dan pemerintah wajib menyediakan sarana dan prasarana pendidikan untuk anak dalam rangka program belajar. Kerena belajar adalah hak, maka belajar harus menyenangkan, kondusif, dan memungkinkan anak menjadi termotivasi dan antusias. Jadi, memaksa anak untuk belajar, sehingga anak merasa tertekan, atau membiarkan anak tidak mendapat pendidikan yang layak adalah tindakan kekerasan. ${ }^{2}$

Oleh karena itu betapa pentingnya pendidikan dimulai dari usia dini, pendidikan anak usia dini memiliki peran yang sangat menentukan. Namun, sayangnya, tingkat kecerdasan masyarakat terhadap layanan pendidikan bagi anak usia dini masih sangat rendah. Hal tersebut disebabkan antara lain kurangngnya sosialisasi kepada masyarakat tentang pentingnya pendidikan anak usia dini. ${ }^{3}$ Sehingga banyak orang tua yang kurang peduli terhadap perkembangan anak, ini menyebabkan terjadinya problematika perkembangan anak seperti perkembangan kecerdasan emosi anak. Para ahli sering mengatakan bahwa banyak generasi sekarang yang cenderung mulai mengalami gangguan emosional seperti: mudah merasa cemas, mudah merasa kesepian, pemurung, mudah frustasi, mudah bertindak agresif, kurang menghargai sopan santun, dan sebagainya. Hal ini disebabkan karena kecerdasan emosi sering dilupakan uapaya pengembangannya pada anak-anak.

${ }^{1}$ Lely Halimah, Perkembangan Kurikulum Pendidikan Anak Usia DIni, (Bandung: Refika Aditama, 2016), h. 2.

${ }^{2}$ Maimunah Hasan, PAUD (Pendididkan Anak Usia Dini), (Banguntapan Jogjakarta: 2010), h. 16.

${ }^{3}$ Mukhtar Latif, dkk, Orientasi Baru Pendidikan Anak Usia Dini, (Jakarta: Kencana, 2013), h. 21-22. 


\section{METODE PENELITIAN}

Penelitian yang dibuat oleh penulis adalah penelitian kualitatif yang menggunakan pendekatan studi kasus, yang mencoba menfokuskan perhatian penelitian pada satu persoalan problematika dan solusi dalam perkembangan anak usia dini (AUD) di TK Aisyiyah Busatanul Athfal Sapen Yogyakarta. Prosedur pengumpulan data yang akan dilakukan oleh peneliti meliputi observasi dan wawancara.

Teknik analisis data yang dipergunakan dalam penelitian ini adalah teknik analisis data Milles dan Huberman, yang berarti bahwa penulis harus melakukan analisa sepanjang penelitian dilakukan, selama penulis melakukan penelitian terhadap masalah yang diteliti, selama itulah penulis tetap melakukan analisa data. Teknik analisis data yang digunakan adalah deskriptif naratif. Teknis ini menurut Milles dan Huberman dalam Jama'an Satori dan Aan Qomariah ${ }^{4}$ diterapkan melalui tiga alur, yaitu: reduksi data (reduction), penyajian data (data display), conclusion drawing/verification.

\section{HASIL DAN PEMBAHASAN}

\section{Problematika Perkembangan Anak Usia Dini (AUD)}

1. Memanjakan anak

Memanjakan anak adalah perilaku yang tidak baik bagi perkembangan kepribadian anak, yang sering digunakan untuk segala macam hal yang buruk, dan memberikan kasih sayang yang sangat berlebihan sampai memberikan apa saja yang menyenangkan anak mislanya dengan memberikan sesuatu dengan harga yang super mahal dan mewah. Sikap memanjakan anak dapat terlihat dari pemuasan kebutuhan anak secara berlebihan, serta kurangnya pengawasan dari orang tua. Memanjakan anak sering dilakukan oleh orang tua yang sangat sibuk dengan alas an memenuhi segala sesuatu yang diinginkan oleh anak, sebagai ungkapan rasa kasih sayangnya kepada anaknya karena tidak dapat menyertai anaknya secara optimal sebagai akibat dari kesibukannya.

Kasih sayang orangtua kepada anak tidak berarti menuruti semua keinginan anak. Berbagai keinginan seharusnya dituruti secara wajar saja. Apabila perlu, kita menolak keinginan anak, ada baiknya seorang anak merasakan kecewa atas keinginannya yang tidak terpenuhi. Rasa kecewa ini, merupakan sebuah pembelajaran yang sangat berarti dan dapat mendewasakan kepribadian anak. Karena sikap memanjakan anak hanyalah akan mengakibatkan anak tergantung pada orangtuanya, selalu mementingkan kepentingan dirinya sendiri. Selain itu memanjakan akan membunuh potensi anak, sebab anak yang dimanja selalu mendapat kesenangan dan kepuasan tanpa bersusah payah, maka potensi

${ }^{4}$ Djam'an Satori dan Aan Qomariah, Metode., h. 218. 
yang ada pada anak tidak terasah. Akibatnya anak akan tumbuh dengan menjadi pribadi yang lemah, yang tetap dalam ketergantungan dengan orang lain.

2. Membanding-bandingkan anak

Kebanyakan orang tua kurang menyadari bahwa sesungguhnya anak-anak sensitif terhadap perasaan orang tua. Apabila seorang anak tidak disukai oleh orang tuanya, maka ia akan breaksi. Membandingkan anak yang satu dengan anak yang lain akan membuat kecil hati anak yang dibandingkan. Mental anak jatuh, dan membuatnya semakin tertakan. Keadaan ini sangat merugikan perkembangan jiwa anak. Membanding-bandingkan kemampuan, pribadi, atau penampilan anak seorang anak dengan orang lain hanya akan mempertajam persaingan, perbedaan, permusuhan, dan kebencian antar anak-anak. ${ }^{5}$ Bahkan kadang-kadang orang tua terlalu menuntut pada anak untuk menjadi yang terbaik, sementara potensi anak yang dimiliki tidak memadai. Akibat yang timbul adalah anak menjadi males belajar dan malas sekolah. ${ }^{6}$

3. Melakukan kekerasan terhadap anak

Tindakan kekerasan yang dilakukan orangtua kepada anaknya memiliki dampak yang dapat merugikan perkembangan anak. tindakan kekerasan tidak selalu berupa kekerasan secara fisik yang berupa pukulan dan hukuman lain yang menyebabkan anak cacat, akan tetapi kekerasan dapat pula berupa kekerasan mental, seperti membentak dan mengancam, memanggil anak dengan kasar dan panggilan bodoh, malas dan sebagainya. Dan ternyata membentak anak merupakan jenis kekerasan yang sering dilakukan oleh orangtua di rumah. Bahkan, bayi pun sering kena bentakan orangtuanya. Terutama orangtua yang masih muda usia. Hal ini mempunyai efek psikologis jangka panjang bagi anak, meskipun secara hukum belum dapat dikatakan sebagai tindakan kekerasan terhadap anak. akibat dari tindakan ini adalah anak menjadi sulit beradaptasi, menjadi pemberontak atau anak yang kurang percaya diri.

4. Pilih kasih

Ternyata, banyak hal yang perlu diperhatikan oleh orang tua dalam bersikap terhadap anak-anaknya. Semua orang tua ingin memberi sesuatu yang terbaik buat anaknya demi masa depannya. Dalam mengupayakan hal ini disadari atau tidak, terkadang orang tua sering melakukan hal-hal yang dapat melukai perasaan anak, yakni melakukan tindakan pilih kasih terhadap anak. Dan terkadang ketika orang tua telah berusaha membuat anak-anak merasa sama-sama dicintai pun, anak-anak menyalahkan orang tua yang menunjukkan sikap pilih kasih. Sampai dititik ini, orang tua tidak sengaja membuat salah satu anak kurang dicintai. Dan apabila tidak hati-hati, prilaku orang tua yang tidak 
kentara ini, dari hari ke hari dapat menimbulkan berbagai perasaan kecemburuan yang berakibat buruk diantara saudara kandung. ${ }^{7}$

5. Janji yang tidak di tepati

Semua orang tua tentu ingin anaknya bahagia. Salah satu carany adalah menjanjikan suatu hal kepada mereka. Anak pasti merasa senang jika orang tuanya berjanji akan memberi hadiah atau mengajaknya pergi ketaman hiburan. Membayangkan senangnya mendapat hadiah atau asyiknya berjalan-jalan membuat anak menanti-nantikan janji itu dengan sepenuh hati. Ketika orang tua berjanji kepada anaknya yang berusia tiga tahun pergi ke taman Safari minggu depan, sejak saat itu juga anak mulai membayangkan apa yang akan ia lakukan di taman Safari. Kemungkinan ia terus-menerus membayangkan akan melihat gajah, harimau, dan hewan-hewan lainnya. Hal itu akan membuat harapan si kecil semakin hari semakin kuat untuk segera pergi ke taman Safari.

Hal penting yang harus diperhatikan oleh para orang tua dalam berjanji adalah dapatkah orang tua menepati janji? Salah satu akibat dari janji yang tidak ditepati adalah munculnya kemarahan pada anak. Kemarahan ini tidak boleh dianggap sebagai perkara yang mudah karena dapat mengakibatkan pengaruh yang buruk pada hubungan anak dan orang tua.

6. Dipaksa disiplin

Setiap orang tua meyakini bahwa pembentukan disiplin pada anak merupakan sebuah proses yang harus mulai ditanamkan sedini mungkin. Orang tua tentu berusaha mengajarkan disiplin kepada putra-purinya dengan cara menanamkan tingkah laku yang dianggap baik dan menghindari tingkah laku yang buruk. Dalam rangka mendisiplinkan anak, setiap keluarga mempunyai peraturan yang harus dipatuhi oleh seluruh anggota keluarga. Peraturan tersebut dapat bermacam-macam, mulai dari tata cara makan hingga sopan santun dalam keluarga. Aturan-aturan yang diterapkan setiap keluarga mungkin berbeda-beda. Aturan yang biasanya diterapkan adalah aturan waktu tidur anak sebelum jam 8 malam. ${ }^{8}$

Penerapan disiplin tidak selamanya dapat diterima dengan sepebuh hati oleh anak. Anak mungkin tidak menyukai aturan yang diterapkan oleh orang tuanya. Akibatnya, anak merasa terpaksa dalam menjalankan disiplin. Reaksi anak terhadap keterpaksaan ini adalah rasa marah yang dapat ditunjukkan dengan cara beragam, tergantung kepribadian anak. seorang anak dapat menunjukkan ke marahannya secara jelas kepada orang tuanya dengan sengaja melanggar aturan yang telah ditetapkan.

${ }^{7}$ Ibid., h. 185.

${ }^{8}$ Seto Mulyadi, Seri Cerdas Emosi: Membantu Anak Balita Mengelola Amarahnya, (Jakarta: Erlangga, 20040), h. 27-36. 
7. Cemburu pada saudara

Rasa cemburu antara adik dan kakak dalam sebuah keluarga merupakan hal yang wajar. Cemburu tersebut merupakan reaksi normal yang dialami manusia karena takut akan kehilangan kasih sayang atau persaan terancam kehilangan yang disayangi. Hal ini wajar dialami oleh seorang anak yang akan memperoleh adik baru. Bagi kakak, sang adik dianggap sebagai saingan yang akan merebut cinta kasih dan perhatian orang tua yang selama ini ia dapatkan. Rasa cemburu muncul karena ia merasa khawatir akan kehilangan apa yang selama ini ia dapatkan dari orang tuanya.

Rasa cemburu pada anak dapat mengakibatkan reaksi marah kemarahan ini timbul karena anak merasa saling bersaing untuk mendapatkan perhatian dari orang tua. Cara anak menunjukkan rasa cemburunya bisa bermacam-macam. Hal ini dipengaruhi oleh faktor usia anak. Anak-anak yang masih kecil cenderung menunjukkan rasa cemburunya secara langsung dan dengan cara yang agresif.

Kecemburuan pada anak dapat mengarah pada persaingan antar saudara, yaitu membentuk kompetisi antar saudara dalam satu keluarga yang bertujuan untuk mendapatkan perhatian dan pengakuan dari orang tua. Adanya persaingan seperti ini kadang membuat anak menjadi semakin marah. Anak dapat merasa tidak aman dalam melakukan hubungan dengan orang yang dicintai dan khawatir kehilangan kasih sayang.

8. Meniru

Menurut Dr. Elizabeth Hurlock, keluarga berpengaruh pada pemberian nilai, pengatahuan, dan perilaku anak. Sikap orang tua berpangaruh pada perilaku anak. Menurut Turner, anak akan mengembangkan sifat pemarah jika mereka memilki orang tua yang pemarah. Selain itu, pengaruh teman sebaya dan televise berperan dalam membentuk perilaku marah anak. Dengan mengamati hal-hal yang membangkitkan emosi tertentu pada orang lain, anak juga akan bereaksi dengan ekspresi yang sama dengan orang yang diamatinya. Misalnya anak melihat orang tuanya selalu marah jika tidak berhasil memperoleh apa yang diinginkan, anak juga akan mempelajari hal yang sama.

9. Orang tua terlalu mendikte

Kebiasaan orang tua mengatur semua keperluan anak dapat membuat anak menjadi tergantung kepada orang tua. Anak pun menjadi tidak mandri dan cenderung mengandalkan orang tua, serta tidak mau berusaha sendiri karena ia berpikir bahwa orang tuanya akan selalu ada untuk membantu. Hal ini akan dapat dipengaruhi pada masa dewasa anak. Ia dapat tumbuh menjadi pribadi yang tergantung pada orang lain. ${ }^{9}$

${ }^{9}$ Ibid., h. 48-51. 
10. Anak suka berkata kotor

Tak jarang dalam kehidupan sehari-hari sering menemukan anak usia dini yang suka berkata kotor atau berkata dengan tidak sopan. Kata-kata kotor yang diucapkannya pada dasarnya keluar karena memang ia sering mendengarkan kata-kata tersebut dari orangorang yang ada disekitarnya, termasuk dari orang tuanya. Biasanya kata-kata kotor dikeluarkan oleh seseorang ketika menghadapi situasi ataupun kondisi yang tak diinginkannya.

Semakin sering anak mendengar kata-kata kotor, maka akan semakin tertanam kuat kata-kata kotor tersebut dalam ingatan anak. ketika anak menemukan suatu situasi ataupun kondisi yang sama persis dengan situasi dan kondisi yang ia dapatkan manakala seseorang berkata kotor, maka pada saat itulah ia berkata kotor. Misalnya saja ketika anak dihina oleh temannya, ia akan berkata kotor kepada temannya karena ia pernah melihat dan mendengar orang tuanya berkata kotor ketika dihina orang lain. Ketika anak kena marah oleh ibunya, ia akan berkata kotor karena pernah melihat dan mendengar ayahnya berkata kotor kepada ibunya saat ayah ditegur ibu. ${ }^{10}$

11. Anak suka bohong

Pada anak yang lebih besar (lima sampai tujuh tahun), bohong merupakan bagian dari strategi mereka untuk memecahkan persoalan dan menghindari hukuman. Kebohongan sudah dilakukan dengan kesengjaan, dalih yang mereka buat sudah lebih masuk akal. Pada usia ini sesekali anak tidak ragu untuk mentes keterampilan untuk berbohong. Di usia-usia ini anak sudah bisa berbohong dengan sangat meyakinkan. Mereka menutupi ekspresi wajah dan bahasa tubuh mereka, sehingga membuat orang tua lebih muda percaya. ${ }^{11}$

12. Kecemasan karena berpisah

Timbul kekhawatiran yang berlebihan dari pihak orang tua tentang kondisi anaknya. Akibatnya muncul keragu-raguan dalam mendidik anak, sehingga akan mengembangkan sikap ragu-ragu serta rasa tidak percaya diri. Oleh karena itu orang tua didorong untuk tidak terlalu protektif dan mengekang anak serta dianjurkan untuk membiarkan anaknya berkembang secara normal. Kecemasan karena berpisah mungkin anak mengalami stress. Kebanyakan anak akan mengalami kecemasan jika berada dalam situasi yang tidak dikenalnya dengan baik, terutama jika bepisah dengan orang tuanya. Anak mengalami persaan takut, merasa terancam dan tidak aman. Gejala bisa berupa: kesedihan yang berlebih ketika berpisah dengan ibu, khawatir akan kehilangan atau terjadi sesuatu yang

${ }^{10}$ Novan Ardy Wiyana, Psikologi Perkembangan Anak Usia Dini, (Yogyakarta: Gava Media, 2014), h. 184-185.

${ }^{11}$ Chris Verdiansyah, Membangun Komunikasi Bijak Orangtua dan Anak, (Jakarta: Gramedia, 2007), h. 13. 
buruk pada ibunya, seing enggan pergi ke sekolaah atau tempat lainnya karena takut berpisah. ${ }^{12}$

\section{Solusi Perkembangan Anak Usia Dini (AUD)}

1. Kesiapan orang tua

Cara berpikir moral kognitif melalui pertimbangan moral yang harus menjungjung tinggi dan mebela nilai-nilai kemanusiaan juga belandas pada prinsip. Oleh karena itu, pembentukan kepribadian anak dirumah melalui peningkatan pertimbangan moral anak yang dilakukan oleh orang tua juga harus berlandas pada prinsip kemerdekaan, kesamaan dan saling terima. Artinya apa pun yang dipikirkan dan dilakukan oleh orang tua di rumah dalam intraksi dan komunikasinya harus dapat dikembalikan pada nilai-nilai kemerdekaan, kesamaan, dan saling terima. Orang tua adalah kunci utama yang harus terlebih dahulu benar-benar memahami dan mampu menerapkan nilai-nilai dari prinsip itu.

Semestinya orang tua dalam satu rumah tangga harus benar-benar telah memiliki kepribadian yang baik dan mantap dalam nuansa moralitanya. Memiliki kepribadian yang mantap dalam nuansa moralitas bagi orang tua dalam sautu rumah tangga, tampaknya bukan sesuatu hal yang mudah. Nilai-nilai yang terkandung dalam prinsip kemerdekaan, persamaan, dan saling terima tidak gampang diterapkan dalam cara berpikir dan bertindak pada suatu keluarga. ${ }^{13}$

2. Membangun hubungan dengan anak

Orang tua sangat disarankan untuk membangun hubungan baik dengan anak. Bahkan menurut Runkel The Revolutionary Approach To Raising Your Keeping Your Cool, (pengasuhan yang bebas dari teriakan: pendekatan revolusioner untuk meningkatkan anak dengan menjaga emosi, dalam pertarungan hubungan, tidak ada pemenang, yang ada hanya korban saja. Orang tua memiliki hubungan yang kuat dengan anak-anak mereka melakukan penyetoran yang jauh lebih besar dari penarikan setiap harinya. Seorang ayah jika menghabiskan waktunya 7 menit atau 11 menit itu merupakan sesuatu yang sangat baik. Oleh karena itu orang tua harus benar-benar mengenal anaknya, untuk mengetahui apa pertimbangan mereka sebagai intraksi positif atau negatif dengan orang tuanya.

Kemudian orang tua ciptakan waktu yang berkualitas untuk dihabiskan bersama keluarga. Orang tua harus memberitahu anak-anak segala sesuatu untuk kebaikan mereka sendiri. Memberitahu kepada mereka 5 sampai 10 kali atau menunjukkan kepda mereka betapa istimewanya mereka bagi orang tua. Dan membiasakan makan malam bersama keluarga, mengikut sertakan anak-anak dan orang tua membantu dalam menyiapkan makan malam. Atau membuat kencan dengan anaknya dengan menikamti kebersamaan

\footnotetext{
${ }^{12}$ Teguh Wiyono, dkk, Rahasia Mendidik Anak Cerdas, (Jakarta Selatan: Suka Buku, 2013), h. 158-159.

${ }^{13}$ Sjarkawi, Pembentukan Kepribadian Anak, (Jakarta: Bumi Aksara, 2006), h. 78-79.
} 
dengan masing-masing anaknya dan membuat anak merasa istimewa, karena orang tua selau memberikan waktu hanya untuk mereka. ${ }^{14}$

3. Mendengarkan anak

Cara lain anak agar hormat dengan orang tuanya adalah dengan meluangkan waktu untuk mendengarkan mereka. Anak-anak merasa senang jika didengarkan. Orang dan anak terkadang duduk bersama, mewarnai dan membicarakan hal-hal yang sangat sepele bagi orang tua, tetapi menurut anak-anak penting. Sama pentingnya juga, jika anak tahu bahwa orang tua bersedia mendengar, maka anak akan menghamipri orang tuanya dan membicarakan apa yang ada dalam pikiran mereka. Biasanya anak memanfaatkan waktu yang orang tua tak duga-duga, seperti pada saat orang tuanga menyiapkan makan malam atau menyapu halaman.

Anak-anak mau bicara saat mereka merasa aman, bukan saat orang tua merasa sempat untuk mendengar mereka. Jadi sebelum orang tua menghabiskan akhir pekan untuk bekerja dikantor atau mengerjakan pekerjaan rumah tangga, sebaiknya orang tua meluangkan waktu untuk anaknya. Karena orang tua yang mendengarkan anaknya serta memberikan perhatian maka hubungan dengan anak akan membaik. ${ }^{15}$

4. Membiasakan memuji anak

Seharusnya orang tua bagaimana kapan kapan memuji. Sebagai orang tua harus menjadikan kebiasaan sehari-hari untuk mencari dan mengidentifikasi usaha anak untuk berprilaku baik, dan menanggapi dengan perhatian positif. Semakin cepat orang tua membiasakan memuji anak tanggapan tanpa sadar terhadap prilaku anak yang disukai, semakin cepat anak akan mulai meningkatkan dirinya demi mendapatkan perhatian positif dan akan berhenti menjadi tukang perintah yang tidak menyenangkan.

Orang tua yang sering memuji anaknya secara konsisten selama seminggu akan menghasilkan:

a. Perilaku yang orang tua puj akan semakin sering dilakukan.

b. Anak akan merasa lebih baik, lebih dihargai.

c. Orang tua merasa lebih baik.

d. Hubungan keluarga akan makin baik.

e. Stress akan makin berkurang bagi semuanya. ${ }^{16}$

5. Peluk dan cintai anak

Orang tua harus selalu mengayun, memegang, memeluk dan mengasihi anaknya. Sentuhan orang tua akan mendorong perkembangan otak yang sehat, jaringan neuron

\footnotetext{
${ }^{14}$ Marcia, Menyiapkan Anak Untuk Sukses di Sekolah dan Kehidupan, (Jakarta: Indeks, 2013), h. 9.

${ }^{15}$ Ray Levy, Cara Membesarkan Anak yang Suka Melawan Tanpa Harus Hilang Kesabaran, (Jakarta: Gramedia Pustaka Utama, 2002), h. 96-97

${ }^{16}$ Cynthia Whitham, Mengatasi Rengekan \& Perilaku Buruk, Anak, (Jakarta: Gramedia, 2003), h. 6.
} 
atau sel otak, menumbuhkan indra pengalaman kita dan mulai membentuk pola-pola untuk pembelajaran. Orang tua harus mengambil waktu untuk mengayun, memeluk, memegang dan mencintai anaknya. Hal ini tidak hanya memberikan rasa aman untuk anak, tetapi juga dapat menyebabkan perkembangan otak yang sehat.

Memberikan sinyal yang hanya diketahui oleh anak untuk melambangkan cinta dan kasih sayang satu sama lain. Gunakan pada waktu tertentu sepanjang hari, seperti ketika mengantar anak-anak kesekolah atau membawa anak dalam perlombaan. Kemudian sebagai orang tua menghilangkan sentuhan negative, seperti menarik pakaian atau lengan anak-anak, menyambar mereka atau memukul mereka. Interaksi negative ini jika digunakan secara berlebihan dapat menghancurkan hubungan orang tua dengan anak, dan menciptakan anak yang pemarah. ${ }^{17}$

6. Meningkat motivasi anak

Anak-anak pada umumnya mempunyai keinginan yang luar biasa dan sulit dicegah. Ia akan mati-matian apapun harus dilakukan dan bagaimana pun sulitnya akan dijalankannya. Dalam hal ini orang tua memberikan kepercayaan kepada anak, namun tetap siap memberikan bantuan jika diperlukan.

Orang tua dapat mengamati beberapa gejala seorang anak memilkik motivasi internal yang tinggi, bila:

a. Mempunyai tujuan yang jelas yang ingin dicapainya.

b. Tantangan yang dihadapi sesuai dengan kompetensi yang dimilikinya.

c. Menggunakan konsentrasi yang luar biasa tinggi.

d. Sering samapi lupa yang lain.

e. Aktivitas yang dikerjakan original dating dari idenya sendiri.

Umumnya anak yang cerdas memiliki tingkat aktivitas yang tinggi, banyak bergerak, selalu eksploratif, karena tengah mencari sesuatu yang menarik dirinya. Jika ia sudah menemukan sesuatu yang menarik, ia akan tenggelam dengan konsentrasi yang tinggi. Sekalipun demikian sering kali seorang anak mengalami kesulitan untuk menguasai salah satu atau dua bidang minatan menjadi suatu prestasi yang luar biasa. Karena itu orang tua perlu membantunya agar anak tatap mempertahankan motivasinya dengan kapasitas yang dimilikinya.

Ada beberapa hal yang perlu diperhatikan :18

a. Bantulah anak agar tetap antusias asik mengerjakan kegiatannya.

b. Sediakan tempat anak yang bisa ia berkonsentrasi.

c. Buatlah jadwal bersama anak.

d. Damping anak sampai selesai mengerjakan kegiatannya.

${ }^{17}$ Marcia, Menyiapkan Anak Untuk Sukses di Sekolah dan Kebidupan, h. 24-26.

${ }^{18}$ Julia Maria Van Tiel, Deteksi dan Penangana Anak Cerdas Istimewa, (Jakarta: Prenada, 2015), h. 136-137. 
e. Bantulah anak kegiatan yang membuatnya bosan.

f. Ajarkan anak untuk menyelesaikan tugas.

g. Bantulah anak untuk menikmati hasilnya pada saat anak telah siap menyelesaikan tugasnya.

7. Kelilingi anak dengan lingkungan yang tenang

Orang tua wajib memberikan lingkungan yang tenang terhadap anaknya, karena dengan lingkungan yang tenang akan sangat membntu perkembangan pada otak anak. Orang tua harus memahami akan efek dari warna pada otak anak, ketika memutuskan warna apa yang akan dipakai untuk mengecat kamar anak. Warna yang menyenangkan bagi mereka yang lebih mungkin yaitu warna pastel, seperti warna hijau atau warna-warna yang sangat terang. Karena fakta yang perlu diingat anak akan menggunakan ruangan yang sama untuk bermain dan tidur.

Ketika orang tua bekerja dengan anak, orang tua perlu untuk menulis sesuatu, ditulis dengan sipidol biru. Hal-hal yang perlu orang tua berikan untuk menarik perhatian anakanak. seperti tanda baca atau kosa kata penting, mungkin harus ditulis dengan warna merah. Penilitian telah menunjukkan bahwa menggaris bawahi konsep-konsep kunci dari kata penting dengan sipidol berwarna cenderung meningkatkan daya ingat dan pengenalan visual. Jika anak-anak ingin melepas lelah dan bersantai, putarlah musik yang menyenangkan. Bahkan saat dalam perjalanan panjang, putar music yang menyenangkan di dalam mobil. Dan perhatikan argumendan pertanyaan-pertanyaan yang mengganggu dari anak-anak. seperti, kapan kita akan sampai disana? Mulailah relaksasi, atau bahkan tidur.

Saat anak-anak ingin mengerrjakan pekerjaan rumah, seperti memecahkan soal matematika, pasanglah musik yang menyenangkan sebagai latar belakang. Jika anak -anak mencoba menghapal sesuatu dan musik mengganggunya, maka hentikan musik tersebut. Karena sebagian anak suka belajar dengan diiringi musik yang menyenangkan. ${ }^{19}$

8. Menekankan hal-hal positif

Sebagai orang tua harus memastikan dan menyediakan lingkungan yang positif di dalam rumah. Setiap anggota keluarga harus selalu menanti/berharap pulang kerumah untuk pulan kerumah setiap hari. Ramah harus selalu aman dan baik secara fisik dan psikologis, dan bebas dari ancaman. Senyum, tawa, hubungan yang akrab, dan rasa memiliki harus melekat dalam intraksi sehari-hari yang terjadi sehingga bahkan ketika orang tua berbicara dengan anak yang mungkin tidak sesuai dengan keinginana mereka, anak-anak akan mengetahui bahwa orang tua memiliki kepentingan yang terbaik dihati mereka.

${ }^{19}$ Marcia, Menyiapkan Anak. Untuk Sukses di Sekolah dan Kebidupan, h. 37-38. 
Berilah inspirasi pada anak-anak untuk belajar secara alami demi kepentingan pembelajaran tanpa menyuap atau memaksa anak-anak. Karena belajar adalah naluri untuk bertahan secara alami termotivasi untuk melakukannya. Bahkan apa yang kita pelajari dengan senang hati, anak tidak akan melupakannya. Jika orang tua sudah memulainya dengan suap, perlahan-perlahan hilangkan kebiasaan itu dari waktu ke waktu. Orang tua memisahkan prilaku anak dengan sesuatu yang pribadi orang tua. Meskipun orang tua tidak suka melakukannya, anak perlu mengetahui bahwa tindakannya yang tidak pantas, tetapi tidak mengubah cinta yang tak bersyarat untuk anak.

Orang tua memberikan pilihan alternatif positif dari pemberian penghargaan. Misalnya biarkan anak untuk menentukan urutan dan menyelesaikan tugas-tugas atau bergantian memilih restoran dimana kelaurga makan bersama. Kemudian tinggalkan catatan positif atau pesan tertulis khusus untuk anak-anak di temapat-tempat yang strategis.

\section{Analisis Problematika dalam Perkembangan Anak}

Dilihat dari hasil observasi dan wawancara peneliti tentang problematika dan solusi perkembangan anak di TK Aisyiyah Bustanul Athfal Sapen Yogyakarta antara lain:

1. Anak berbicara yang kurang sopan, berdasarkan wawancara dengan orang tua murid, ketika anak pulang dari sekolah, tiba -tiba cara berbicara anak kurang sopan. Biasanya bahasa daerah yang sering digunakan anak yang kurang sopan untuk diaplikasikan anak di rumah.

2. Anak terlalu di dikete, orang tua selalu mengatur keperluan anak, tanpa memberikan kesemapatan anak untuk mandiri dengan baik.

3. Orang tua sering menjanjikan untuk membelikan sesuatu, tetapi belum tentu dipenuhi oleh orang tua, biasanya untuk membelikan mainan. Sehingga anak sering merasa kecewa.

4. Anak susah diatur, guru sering membiarkan anak-anak yang susah diatur, karena semakin di tegur anak semakin menjadi-jadi untuk terus bermain ketika guru mengajar. Ini biasanya anak yang sering dimanjakan oleh orang tuanya. Sehingga anak sesuka hati disekolah.

5. Anak masih merasa cemas untuk berpisah, anak yang masih cemas untuk berpisah orang tuanya selalu mengantar anaknya sampai ke dalam kelas. Karena anak tersebut merasa masih cemas ketika di tinggal oleh orang tuanya.

Kemudian untuk solusi dalam perkembangan anak, orang tua jangan membiasakan menuruti semua kemauan anak, apalagi dalam hal mempersiapkan kebutuhan anak, biasakan anak untuk mandiri melakukan kegiatan sehari-hari semampu anak. Orang tua tidak boleh menjanjikan sesuatu yang tidak ditepati untuk anak, itu akan mengajarkan anak berbohong. 
Membiasakan anak berbicara dengan sopan, dan biarkan anak mengembangkan kreativitasnya sendiri, tanpa memaksa anak harus menjadi orang lain.

\section{SIMPULAN}

Pendidikan anak usia dini merupakan masa emas yang hanya datang sekali dan tidak dapat diulang. Anak usia dini berada dalam masa keemasan yang mana pada masa periode sensitif yang mana anak secara khusus mudah menerima berbagai stimulus dari lingkungannya. Bahkan sekitar 50\% kecerdasan orang dewasa sudah terjadi ketika berumur 4 tahun.

Oleh karena itu sebagai orang tua wajib untuk melihat perkembangan anak. karena upaya untuk menstimulus anak sejak dini sangat penting. Dan betapa ruginya keluarga, atau orang tua yang tidak peduli dengan perkembangan anak. Sebab pada masa usia dini masa yang tepat untuk mengembangkan aspek fisik-motorik, kognitif, sosial-emosi, bahasa dan moral anak.

Jadi sebagai orang tua harus memahami pertumbuhan dan perkembangan anak, dan mengerti akan kebutuhan anak sesuai dengan umurnya, tanpa harus memaksa anak dengan kekerasan. Tetapi mendidik anak dengan menyenangkan serta penuh dengan cinta dan kasih sayang.

\section{DAFTAR PUSTAKA}

Lely Halimah, Lely. Perkembangan Kurikulum Pendidikan Anak Usia DIni, Bandung: Refika Aditama, 2016.

Hasan, Maimunah. Hasan, PAUD (Pendididkan Anak Usia Dini), Banguntapan Jogjakarta: 2010.

Latif, dkk., Mukhtar. Latif, dkk, Orientasi Baru Pendidikan Anak Usia Dini, Jakarta: Kencana, 2013.

Ray Levy, Ray. Cara Membesarkan Anak yang Suka Melawan Tanpa Harus Hilang Kesabaran, Jakarta: Gramedia Pustaka Utama, 2002.

Marcia, Menyiapkan Anak Untuk Sukses di Sekolah dan Kehidupan, Jakarta: Indeks, 2013.

Seto Mulyadi, Seto. Seri Cerdas Emosi: Membantu Anak Balita Mengelola Amarahnya, Jakarta: Erlangga, 20040.

Pamilu, Anik., Mendidik Anak Sejak Dalam Kandungan, Yogyakarta: Citra Media, 2007.

Wiwien Dinar Prastisti, Wiwien Dinar. Psikologi Anak Usia Dini, Jakarta: PT Indeks, 2008.

Sjarkawi, Pembentukan Kepribadian Anak, Jakarta: Bumi Aksara, 2006.

Julia Maria Van Tiel, Julia Maria Van. Deteksi dan Penangana Anak Cerdas Istimewa, Jakarta: Prenada, 2015. 
Chris Verdiansyah, Chris. Membangun Komunikasi Bijak Orangtua dan Anak, Jakarta: Gramedia, 2007.

Cynthia Whitham, Cynthia. Mengatasi Rengekan \& Perilaku Buruk Anak, Jakarta: Gramedia, 2003.

Novan Ardy Wiyana, Novan Ardy. Psikologi Perkembangan Anak Usia Dini, Yogyakarta: Gava Media, 2014.

Teguh Wiyono, dkk., Teguh. Rahasia Mendidik Anak Cerdas, Jakarta Selatan: Suka Buku, 2013. 